Doc. dr. sc. Blanka Kačer ${ }^{1}$,

Pravni fakultet Sveučilišta u Splitu

Lovro Badžim², odvjetnik

\title{
STANDARD DOKAZIVANJA I PRAVNA PITANJA DOPINGA U SUDSKOJ PRAKSI CAS-a, S POSEBNIM NAGLASKOM NA AKTUALNU ODLUKU U PREDMETU SUN YANG
}

\author{
$U D K: 343.57: 796$ \\ $341.6: 796 / 799$ \\ DOI: $10.31141 /$ zrpfs.2021.58.139.291 \\ Pregledni rad \\ Primljeno: 25. listopada 2020
}

\begin{abstract}
U radu se analizira stanje i u pravnoj regulativi i u sudskoj praksi CAS-a, s posebnim osvrtom na konkretnom slučaju. Između ostaloga, zaključeno je u radu da postoji znatna neravnoteža u procesnom položaju stranaka u antidopinškom postupku i da su potrebne promjene de lege ferenda, ali dok do tih promjena ne dođe, da je nužno u svrhu zaštite pravne sigurnosti i vladavine prava primijeniti pravila ciljnog tumačenja.
\end{abstract}

Ključne riječi: doping, pravna pitanja, sudska praksa CAS-a, standard dokazivanja, ciljno tumačenje

\section{UVOD}

Najviša vrednota demokratskih pravnih sustava u svijetu izražena je kroz načelo jednakosti svih ljudi u pogledu zaštite njihovih sloboda i prava. O važnosti načela vladavine prava dovoljno govori činjenica da je to načelo istaknuto u preambuli Konvencije za zaštitu ljudskih prava i temeljnih sloboda.

Samim time, potreba za regulatornom intervencijom, koja se u svijetu sporta pojavila radi borbe protiv dopinga, nužno je morala biti u balansu između zajamčenih sloboda sportaša da obavljaju svoju djelatnost s jedne strane i nametljivih i opterećujućih normi kojim se te slobode ograničavaju, a sve u cilju prevencije

1 Doc. dr. sc. Blanka Kačer, Katedra za građansko pravo Pravnog fakulteta Sveučilišta u Splitu, ravnateljica Poslijediplomskog stručnog studija Športsko pravo, predsjednica Hrvatskog društva za športsko pravo

2 Lovro Badžim, LL.M. (Penn State Law), arbitar na Arbitražnom sudu za sport (CAS) i Arbitražnom sudu Hrvatskog nogometnog saveza, odvjetnik u Odvjetničkom društvu Grahovac, Horvat, Žaper d.o.o., Zagreb 
varanja (zaštite prava svih sportaša), ${ }^{3}$ zaštite zdravlja sportaša ${ }^{4}$ i zaštite ,,sportskog duha“, tj. da pobijedi najbolji ${ }^{5} \mathrm{~s}$ druge strane.

U ovome radu, autori će prikazati na koji se način načelo vladavine prava ostvaruje na polju sportskog prava, konkretnije sportske arbitraže u disciplinskim stvarima, kroz primjenu određenih odredbi Svjetske antidopinške agencije i njihov utjecaj na prava i obveze sportaša. Kao predložak navedenom cilju, autori su upotrijebili recentnu odluku Arbitražnog suda za sport (CAS) u predmetu Svjetske antidopinške agencije (WADA) protiv Sun Yanga i Svjetske organizacije vodenih športova (2020), te sudsku praksu Arbitražnog suda za sport (CAS) u nekim drugim usporednim predmetima. Pri navedenom, svakome je ostavljena mogućnost samostalno zaključiti jesu li fundamentalni razlozi za kodifikaciju antidopinških pravila istaknuti u uvodnom dijelu Pravilnika za borbu protiv dopinga Svjetske antidopinške agencije (dalje: Pravilnik WADA-e) ${ }^{6}$ opravdani, u smislu zasebne pravne naravi tih Pravila koja ,ne podliježu niti su ograničena bilo kakvim nacionalnim zahtjevima i pravnim standardima koji vrijede za kaznene i građanske postupke“, 7 što će autori također analizirati i iznijeti svoj stav na primjeru sudskom praksom ustaljenog standarda dokazivanja u Predmetu Sun Yang i drugim predmetima CAS-a.

\section{KRATKA POVIJEST WADA8-e}

Atribut „kratka“ koji se prigodno (ali i edukativno) navodi uz ovakve dijelove nekog rada (koji objektivno, ipak, nisu ključni) obično baš i ne odgovara pravom

3 Opširnije u Dick Pound, Inside the Olympics, Wiley, Toronto, 2004., str. 60; Michele Verroken, „A time for re-evaluation: the challenge to an athlete's reputation“, Drugs and Doping in Sport, RoutledgeCavendish, 2001., str. 31.

4 Koji cilj neki dovode u pitanje pod obrazloženjem da se ne bi trebalo sankcionirati ako su rizici poznati, izbor samostalan i nitko drugi ne bude oštećen.

5 Adam Lewis, Jonathan Taylor, Sport: Law and Practice, treće izdanje, Bloomsbury Professiona, 2014., str. 136-143.

6 „Programom borbe protiv dopinga nastoji se očuvati temeljna vrijednost sporta. Ta se vrijednost naziva sportskim duhom. Riječ je o biti olimpizma, težnji za izvrsnošću usavršavanjem i njegovanjem vlastitog talenta. To je poštena igra. Sportski duh slavljenje je ljudskog duha, tijela i uma, a zrcali se u vrijednostima koje nalazimo u sportu i baveći se njime. Te su vrijednosti:

- etičnost, fair play i čestitost

- zdravlje

- izvrsnost u izvedbi

- karakter i obrazovanje

- zabava i veselje

- timski rad

- posvećenost i predanost

- poštovanje zakona i propisa

- poštovanje sebe i drugih sudionika

- hrabrost

- zajedništvo i solidarnost.

Doping je u svojoj biti protivan sportskom duhu.“; opširnije u Lewis i Taylor, op. cit., str. 143.

7 Pravilnik WADA-e, Montreal - Quebec (2015.), Predgovor, dostupno na www.wada-ama.org.

8 World Antidoping Agency (Svjetska antidopinška agencija) - WADA. 
stanju odnosno istini. Naime, vrlo često se na taj povijesni pregled ,potroši“ mnogo stranica, što je samo donekle opravdano s obzirom na to da se povijest nečega vrlo često odnosi na razdobje od više (pa i desetaka) stoljeća. Po naravi stvari, povijest WADA-e nije isto što i povijest dopinga, ali više začuđuje koliko je vremena trebalo proći do početka institucionalne borbe protiv dopinga, ${ }^{9}$ a baš to se povezuje s osnivanjem WADA-e.

Za doping (u sportu) slobodno se može kazati da postoji oduvijek, makar je možda pretjerano navesti da postoji od kada postoji i sam sport. Još davno je dolazilo do pojava uzimanja sredstava kako bi netko bio bolji u nečemu čime se bavio. Iako se prima facie čini kako je ideja korištenja nedozvoljenih sredstava vezana za napredak moderne medicine i farmakologije, prvi podaci o dopingu u sportu stari su čak 2700 godina. Stari Grci su na svojim drevnim Olimpijskim igrama koristili određene vrste gljiva kako bi postigli bolje rezultate. Još davne 1904. godine Thomasu Hicksu je za vrijeme maratonske utrke na samoj stazi ubrizgan strihnin, kako bi uopće bio sposoban završiti utrku. Utrku je završio i na njoj pobijedio, osvojivši zlatnu medalju. Iako je potez daleko od viteškog i časnog, zanimljivo je kako nije bio ilegalan. Naime, u to vrijeme nije postojala zabrana ikakvih sredstava, dakle sve je bilo dopušteno (tzv. predmnjeva slobode). ${ }^{10}$ Prva znanstvena kontrola na nedopuštena sredstva u natjecanjima obavljena je 1910. god. i to na konjima. ${ }^{11}$

Nakon što su u Meksiku 1968. uvedena antidopinška pravila, prva osoba kojoj je oduzeta osvojena medalja postao je Hans Gunnar Liljenwall. On se natjecao u modernom pentatlonu, a „pao“ je zbog - dva piva. Prije streljaštva popio je dva piva, a nalazi krvi su pokazali nedozvoljenu supstancu. Zanimljivo bi (možda) bilo provjeriti i de Coubertina, također osvajača zlatne olimpijske medalje. Otac modernih Olimpijskih igra medalju je osvojio u vrlo čudnoj disciplini - najbolja pjesma sa sportskom temom. ${ }^{12}$

Svjetska antidoping agencija (WADA) osnovana je 1999. god. i od svojeg osnivanja surađuje s nacionalnim antidoping agencijama, međunarodnim i nacionalnim sportskim savezima, ali i vladama državama potpisnicama Međunarodne konvencije protiv dopinga u sportu, koja je usvojena 19. listopada 2005. god. u Parizu, a Republika Hrvatska usvojla ju je u srpnju 2007. god..$^{13}$

9 Riječ ,doping“ se, prema nekim navodima, prvi put pojavila u jednom engelskom rječniku označavajući određenu mješavinu opijuma i narkotika. U pogledu korijena riječi postoje različita mišljenja. Prema jednom, riječ vuče korijen iz jednog dijalekta koji se govori u jogoistočnoj Africi, a označava alkoholno piće s vrlo visokim postotkom alkohola koje se koristilo kao stimulans prilikom obavljanja ritualnih obreda. Prema drugom mišljenju, riječ potječe iz nizozemskog jezika, gdje bi riječ „,doop“ označavala gustu tekućinu koja se koristi u cilju povećanja postignuća. - Anja Muller, Doping im Sport als Strafbare Gesundheitsbeschadigung (\&\& 223 Abs, 230 StGB)?, Nomos Verlagsgesellschaft, BadenBaden, 1993., str. 15., prema: Matko Pajčić, Tonći Petković, „Doping i kaznenopravna odgovornost“, Zbornik radova Pravnog fakulteta u Splitu, god. 45., 3/2008, str. 551.

10 Petar Klarić, Martin Vedriš, Građansko pravo, Narodne novine, Zagreb, 2008., str. 233.

11 Dinko Pivalica, „Postupak doping kontrole i terapijska izuzeća“, u: Doping u vrhunskom sportu, Hrvatski olimpijski odbor - Zdravstvena komisija, Zagreb, 2019., str. 65.

12 Vidjeti na: www.telegram.hr, Povijest dopinga..., uvid izvršen 1. V. 2020., 18,00.

13 Zakon o potvrđivanju Međunarodne konvencije protiv dopinga u športu, Narodne novine MU 7/2007. 
Činjenica koju nitko i ne pokušava osporiti jest da je doping jedno od najvećih zala koja prijete sportu i da je apsolutno nužno protiv toga zla boriti se svim mogućim sredstvima. Također, potpuno je jasno da u svojim počecima ta borba, kako bi imala koliko-toliko izgleda na uspjeh, mora i u pravnom dijelu ići izvan tzv. uobičajenih koridora. Međutim, s vremenom objektivno dolazi do promjena, tako da ono što je nekada bilo potpuno prihvatljivo, danas postaje relativno prihvatljivo, a možda će u budućnosti biti potpuno neprihvatljivo. Vrijeme će pokazati gdje je ona prava mjera koja će očuvati učinkovitost, ali i (istodobno) vladavinu prava i pravnu sigurnost. ${ }^{14}$

\section{OSNOVNO O TUMAČENJU U PRAVU}

Tumačenje u pravu možemo, potpuno slobodno, bez ikakvog rizika od pogreške, označiti kao jedno od najvažnijih pravnih pitanja i teorije i prakse. Riječ je o fenomenu koji je na određeni način ambivalentan u smislu da, ovisno o tome kako se društvo u cjelini i njegovi dijelovi postave, može značiti velike probitke - i pravnu sigurnost i vladavinu prava. A contrario, lako je moguće da prevladaju mogući negativni učinci. Tako npr. zakonodavac može izbjegavati svoju odgovornost smatrajući da nema potrebe za novim zakonima ili promjenom starih, kada sve to, što bi se postiglo donošenjem novog zakona ili noveliranjem starog, može biti (lako) postignuto u postupku tumačenja, posebno ciljnog ili teleološkog. U takvom kontekstu i sudovi mogu prihvatiti isti ili sličan modus operandi na način da smatraju da je zadatak zakonodavca izraditi savršenu pravnu normu i da nije na sudovima, na bilo koji način, pravnu normu ,,popravljati“. Sto se tiče izvršne vlasti kao treće grane u poznatoj trodiobi vlasti, za nju na odgovarajući način vrijedi isto što smo naveli za sudove (ako se radi o nižim granama vlasti) ili što smo naveli za zakonodavca, ako se misli na vladu kao onoga tko predlaže daleko najveći dio usvojenih zakona.

Tumačenje prava (engleski statutory interpretation, njemački Rechtsauslegung, francuski interpretation du droit, talijanski interpretazione della legge) djelatnost je kojom se utvrđuje značenje, odnosno smisao neke pravne norme. Tumačenje prava kao takvo je dio opće teorije tumačenja (hermeneutike). Inače, hermeneutika nastaje tek u novije doba, oslanjajući se ponajprije na rezultate nastale u tumačenju prava i svetih spisa. Prve spoznaje datiraju, odnosno nalazimo ih u antičkoj Grčkoj i latinskoj retorici, a zatim i u rimskoj jurisprudenciji. Utemeljene i zaokružene, a poslije i veoma utjecajne doktrine tumačenja prava vežu se za F. K. von Savignyja koji je početkom 19. st. postavio kanone tumačenja prava. Interesantno je da je prema ciljnom tumačenju bio dosta skeptičan, smatrajući da cilj zakona tumač može samo pridodati, ali ne i naći. ${ }^{15}$

Svaka pravna norma predstavlja skup riječi koje imaju određeno značenje (jednina) ili određena značenja (množina) koja tek treba utvrditi. Uslijed čitavog

14 Vidjeti više u: Hrvoje Kačer, Blanka Kačer, „(Poneke) pravne dvojbe u svezi dopinga“, Doping $u$ vrhunskom sportu, Hrvatski olimpijski odbor - Zdravstvena komisija, Zagreb, 2019., str. 84.-99.

15 Pravni leksikon, Leksikografski zavod Miroslav Krleža, Zagreb, 2007., str. 1638. 
niza uzroka (bogatstvo nekog jezika, gramatika) skupu riječi (znakova) često je dosta složeno dati pravo značenje i baš na tom se zadatku vidi, odnosno može vidjeti, vrsnoća ili nevrsnoća onoga tko primjenjuje (tumači) pravnu normu. Postoje općeprihvaćena pravila tumačenja, u dosta velikoj mjeri prihvaćen je i njihov međusobni odnos, ali ipak u praksi dolazi do problema. To je svojstvo kako kontinentalnoeuropskog prava (kojem i mi pripadamo), ali i precedentnog prava, što problem svakako čini još značajnijim. Prije dovršetka procesa tumačenja jednostavno ne možemo kazati što je sadržaj neke pravne norme, drugim riječima condicio sine qua non postupanja lege artis je, prije zaključka o sadržaju prave norme, provesti (potpun i pravilan) postupak tumačenja.

Tumačenje redovito započinje jezičnim tumačenjem koje se dopunjuje, po potrebi i mijenja drugim metodama tumačenja. U biti se radi o argumentima ili razlozima koji nemaju prisilni karakter i koje tumači koriste da bi uvjerili druge kako je njihova odluka ispravna ili da bi uvjerili druge da donesu baš takvu odluku. ${ }^{16}$

Ciljna (teleološka) metoda ${ }^{17}$ tumačenja jest metoda kojom se ispituje uloga pravne norme u društvu i zaključuje da je njeno pravo značenje u određenom pravnom odnosu ono značenje koje najbolje izražava vladajuće društvene ciljeve. Upravo ciljna metoda (kako smo već naglasili) smatra se odlučnom u svim onim slučajevima postojanja više mogućih (vjerojatnih) pravih značenja, pa njena uporaba mora otkriti ono (jedino) pravo značenje te pravne norme. Zbog toga je ciljno tumačenje najvažnije, odlučno i završno u postupku tumačenja (razumijevanja) pravnih normi, a sva druga pravila tumačenja njemu su podređena i njemu služe. ${ }^{18} \mathrm{U}$ slučaju nesuglasja s ciljnim tumačenjem prednost ima (uvijek) ciljno tumačenje. ${ }^{19}$ Teleološkim tumačenjem utvrđuje se pravo značenje pravne norme na osnovi utvrđivanja cilja. Ono se u pretežitom dijelu suvremenih shvaćanja smatra odlučujućim za utvrđivanje pravog značenja norme..$^{20}$

Ono što treba izdvojiti jest vječna dvojba smije li se ciljnom metodom ići izvan onoga što dopušta jezično tumačenje. Jedni smatraju da ciljna metoda služi baš da bi ispravila nejasnoće jezične (u prvom redu, ali ne samo te, nego i drugih) metode, pa to nema svrhe ako joj se postave baš takva ograničenja. Drugi pak smatraju da normotvorac uvijek može normu promijeniti ako njom nije zadovoljan (pa čak i s povratnim učinkom), ${ }^{21}$ pa nema, ni potrebe ni opravdanja, tako teško povrijediti pravnu sigurnost kao što je to slučaj ako se ciljnom metodom utvrđuje

16 Na ovo pojednostavljenje i raskid s određenim zabludama prema kojima su metode siguran način da se dođe do apsolutno istinitih ili pravih značenja pravnih normi odlučno je utjecao razvitak tzv. teorije argumentacije - vidjeti u: Nikola Visković, Teorija države i prava, Birotehnika, Zagreb, 2001., str. 247.

17 Vidjeti više o ovoj metodi, pod slovenskim nazivom Namenska (teleološka) razlaga u: Marijan Pavčnik, Teorija prava, Pravna obzorja, drugo dopunjeno izdanje, Cankarjeva založba, Ljubljana, 2001., str. 403. i dalje.

18 Vidjeti tako u: Nikola Visković, op. cit., str. 250, više o tome i u: Oleg Mandić, Sistem $i$ interpretacija prava, Narodne novine, Zagreb, 1971., str. 201. i dalje.

19 Vidjeti tako u: Nikola Visković, op. cit., str. 249.

20 Pravni leksikon, Leksikografski zavod Miroslav Krleža, Zagreb, 2007., str. 1639.

21 Povratni učinak samo dijela zakona iz posebno opravdanih razloga dopušta Ustav Republike Hrvatske kao iznimku. 
značenje koje nije jedno od onih koje daje jezična metoda. Prihvaćajući postojanje potrebe odstupanja od jezične metode, to bi se (ipak) smjelo dopustiti samo i isključivo kao iznimno rijetka iznimka. Opće pravilo mora biti da se ciljna (ali i svaka druga) metoda moraju kretati u okvirima koje određuje jezična metoda, a iznimka bi samo vrlo iznimno smjela doći u obzir.

\section{4. ČINJENICE SLUČAJA SUN YANG}

Dana 4. rujna 2018. u postupku testiranja sportaša izvan natjecanja - po nalogu Svjetske organizacije vodenih športova (dalje: FINA) kao tijela nadležnog za odobrenje provođenja konkretnog testiranja, Dopinška kotrolorka, Asistent dopinške kontrolorke, te Asistentica za uzimanje uzorka krvi, svi zaposleni u društvu International Doping Tests and Management (dalje: kotrolori IDTM-a), ${ }^{22}$ pokušali su provesti testiranje izvan natjecanja uzimanjem uzorka krvi i urina od kineskog plivača g. Sun Yanga (dalje: Sportaš). Kontrolori IDTM-a testiranju su pristupili u društvu četvrte neidentificirane osobe koja je vozila auto kojim su kontrolori došli. Nakon što su kontrolori IDTM-a legitimirali Sportaša, isti je potpisao obrazac dopinške kontrole i pristao na uzimanje dvaju uzoraka krvi, koji su potom zapečaćeni u staklenim bočicama i odloženi u spremnik. Nedugo nakon toga, Asistent dopinške kontrolorke fotografirao je Sportaša, što je ovaj protumačio neprofesionalnim te ponovno zatražio na uvid njihove akreditacije. Akreditaciju Asistenta dopinške kontrolorke Sportaš je smatrao nepotpunom, pa je uz pristanak Dopinške kontrolorke isti izuzet od daljnjeg postupanja, no kako je izuzeti asistent bio jedina muška osoba među kontrolorima IDTM-a, daljnji postupak (uzimanja uzorka urina) nije mogao biti proveden. Potom je Sportaš izrazio sumnju i u vjerodostojnost akreditacija Dopinške kontrolorke i Asistentice za uzimanje uzorka krvi, te odlučio telefonski kontaktirati svojeg doktora, dr. Ba Zhena, te voditelja kineske plivačke reprezentacije, g. Cheng Haoa, za savjet. Navedeni asistenti su nakon razgovora s Dopinškom kontrolorkom zauzeli stav da akreditacija kontrolora ne ispunjava propisane standarde, te da se uzorci krvi ne smiju odnijeti, slijedom čega ih je Sportaš i oduzeo, prisilivši kontrolorke da mu uzorke predaju, iako su ga ove prethodno upozorile da bi navedeni čin mogao biti protumačen kao kršenje postupka uzimanja uzoraka i imati ozbiljne posljedice. Konotrolorke su posebno napomenule da mu ne mogu ostaviti bilo kakav materijal IDTM-a, slijedom čega je Sportaš naložio pripadniku svojeg osiguranja da razbije stakleni spremnik i ostatke istog, ali bez uzoraka krvi, preda kontrolorima. Pripadnik osiguranja je potom čekićem razbio spremnik, pri kojoj radnji mu je Sportaš mobitelom osvjetljavao posudicu s uzorkom krvi, koju je potom uzeo. Posljedica je navedenih radnji da tu večer nikakav uzorak krvi ili urina nije bio izuzet za analizu. Nastavno, Sportaš je uništio i obrazac dopinške kontrole koji je prethodno bio potpisao, te naložio

22 IDTM je trgovačko društvo koje putem svojih zaposlenih kontrolora provodi antidopinška testiranja po nalogu međunarodnih sportskih federacija, Svjetske antidopinške agencije (dalje: WADA), nacionalnih antidopinških organizacija, samostalnih sportskih organizacija i organizatora natjecanja. 
dr. Ba Zhenu da napiše komentar spornog postupka uzimanja urina na zasebnom komadu papira, koji su potom osim njih dvojice potpisali i kontrolori IDTM-a. Tekst je glasio: „U noći 4. rujna 2018., četiri osobe iz FINA-e provele su tesktiranje krvi i urina g. Sun Yanga. Jedna od četiri osobe bio je vozač bez poveznice s testiranjem. Ostale tri osobe ušle su u sobu. Od tri osobe, Dopinška kontrolorka (broj iskaznice...) posjedovala je akreditaciju dopinškog kontrolora koju je pružila na uvid Sportašu, koji je aktivno surađivao u postupku testiranja. Unatoč tome, u postupku uzimanja krvi i urina, Sportaš je otkrio da je Asistentica za uzimanje uzorka krvi pokazala samo Certifikat kvalifikacije za medicinsku sestru (broj...), ali nije pokazala akreditaciju dopinškog kontrolora za uzimanje uzorka krvi. Asistent dopinške kontrolorke (i njezin školski kolega) zadužen za uzimanje uzorka urina, samo je pokazao svoju osobnu iskaznicu (broj...), dok nije predočio akreditaciju dopiškog kontrolora za urin. Navedene osobe nisu bile u nikakvoj vezi. Na ponovni upit, samo je Dopinška kontrolorka (broj iskaznice...) pokazala akreditaciju, dok druge dvije osobe nisu predočile akreditaciju dopinškog kontrolora ili drugog nadležnog tijela. Stoga se postupak uzimanja uzoraka krvi i urina ne može izvršiti. (Uzorak krvi koji je izuzet, ne može se odnijeti.)." ${ }^{23}$

\subsection{Postupak pred dopinškim vijećem FINA-e}

IDTM je cijeli događaj prijavio FINA-i, koja je zatražila i ishodila očitovanje Sportaša, prema čijim je navodima sporno bilo ponašanje kontrolora IDTM-a. Nakon provedene istrage, FINA je 5. listopada 2018. optužila Sportaša za povredu članaka $2.3^{24}$ i $2.5^{25}$ FINA-inih Pravila dopinške kontrole (dalje: Pravila FINA-e). Sportaš je u pisanom obliku iznio svoju obranu, a u konačnici je Antidopinško Vijeće FINA-e Odlukom od 3. siječnja 2019. utvrdilo:

"7.1 Sportaš nije počinio povredu članaka 2.3 i 2.5 antidopinških Pravila FINA-e;

7.2 Ova Odluka neće biti javno dostupna sukladno članku 14.3.3 Pravila FINA-e, osim ako Sportaš ne pristane na suprotno;

7.3 Kineski plivački savez dužan je snositi sve troškove ovoga postupka sukladno čl. 12.3 Pravila FINA-e;

7.4 Žalbu protiv ove Odluke moguce je podnijeti Arbitražnom sudu za sport (CAS) sa sjedištem u Lausannei, Švicarska, u roku od dvadeset i jednog (21) dana od primitka pisanog i obrazloženog otpravka Odluke (čl. 12.11.4 i 13. Pravila FINA-e). ${ }^{26}$

23 CAS 2019/A/6148, WADA v. Sun Yang i FINA, Pravorijek od 28. II. 2020., str. 4-6.

24 Izbjegavanje, odbijanje ili propuštanje davanja uzorka na analizu.

25 Utjecanje ili pokušaj utjecanja na postupak dopinške kontrole.

26 WADA v. Sun Yang i dr., op. cit., str. 6-7. 


\subsubsection{Obrazloženje Odluke FINA-e}

Sporna odluka FINA-e, u bitnome, sadrži obrazloženje da službena dokumentacija djelatnika Tijela ovlaštenog za prikupljanje uzoraka treba sadržavati: značku ili iskaznicu s fotografijom i drugim podacima službenika; tiskani autorizacijski obrazac s nazivom i logom tijela ovlaštenog za prikupljanje uzoraka, te podacima kontrolora; fotografiju i digitalnu identifikaciju kontrolora na web-stranici; poveznice u digitalnom obliku s detaljima Kontrole. No minimum podataka koje službena dokumentacija Tijela ovlaštenog za prikupljanje uzoraka mora sadržavati jest dokaz veze između Tijela koje prikuplja uzorak, uključenih kontrolora i naloga koji se ispunjava. Nadalje se obrazlaže da nije dovoljno osloniti se na usmenu tvrdnju poznatog kontrolora da su prisutni asistenti (bez službenih akreditacija) „sa mnom, ali sam ja glavni i sve će biti u redu”. Nadalje, u obrazloženju se navodi da postupak uzimanja uzoraka nije pravilno iniciran, na što ukazuje nedostatak službene dokumentacije IDTM-a za Asistenta dopinške kontrolorke i Asistentice za uzimanje uzorka krvi, zbog čega se, dakle, može zaključiti da Sportaš nije pravilno obaviješten o postupku. Također, zahtjev za davanje urina nije niti proveden, dok je uzeti i naknadno uništeni uzorak krvi prikupljen neovlašteno i stoga se ne može smatrati uzorkom kako je taj pojam definiran u Pravilima FINA-e. Slijedom navedenog, postupak uzimanja urina od 4. rujna 2018. ništetan je, pa nema osnove da iz navedenog postupka bude utvrđena povreda Pravila FINA-e. ${ }^{27}$

No, čak i kada utvrđene manjkavosti ne bi bile dostatne za poništaj postupka prikupljanja uzorka, postoje i druge okolnosti na temelju kojih se može zaključiti da Sportaš nije prekršio Pravila FINA-e. Prvenstveno, to se odnosi na neprofesionalnost Asistenta dopinške kontrolorke koji je potajno snimao i fotografirao Sportaša - što je samo po sebi dovoljan razlog za momentalnu suspenziju kontrolora, koji je trebao nadzirati Sportaša prilikom davanja uzorka urina, kao i osnovani razlog Sportašu da odbije bilo kakav daljnji kontakt s navedenim kontrolorom. Potom, činjenica je da Asistentica za uzimanje uzorka krvi nije predočila valjanu akreditaciju, a time ni dokazala svojstvo ovlaštene osobe da provede uzimanje krvi, što je uvjet propisan WADA-inim Međunarodnim standardom za testiranje i istrage, ${ }^{28}$ stoga se krv koju je takva neovlaštena osoba uzela testiranoj osobi ne bi mogla smatrati "uzorkom" u kontekstu Pravila FINA-e.

Nadalje, Dopinška kontrolorka nije dovoljno jasno i jezikom koji Sportaš razumije artikulirala posljedice koje će uslijediti u slučaju da Sportaš odbije postupiti po njezinu nalogu, što je uvjet propisan Aneksom A 3.3.a ISTI-ja, već se koncentrirala na raspravu tko je u pravu i bi li eventualno ovakav rasplet mogao biti tumačen kao odbijanje postupanja. ${ }^{29}$

\footnotetext{
27 Ibid., str. 7-8.

28 Eng. International Standard for Testing and Investigations (dalje u tekstu: ISTI).

29 WADA v. Sun Yang i dr., op. cit., str. 8-10.
} 


\subsection{Postupak pred Arbitražnim sudom za sport (CAS)}

Dana 14. veljače 2019. WADA je podnijela Arbitražnom Sudu za Sport (CAS) Izjavu o žalbi ${ }^{30}$ protiv sporne odluke FINA-e sukladno članku R48 Pravilnika CASa. ${ }^{31}$ Osim Sportaša, tuženik u postupku bila je i FINA.

\subsubsection{Prigovor imenovanja Arbitra}

WADA je kao arbitra u predmetnom postupku imenovala Michaela J. Beloffa, odvjetnika u Londonu, UK, koju nominaciju je Sportaš osporio, slijedom čega je konačnu odluku trebala donijeti Komisija za rješavanje spornih imenovanja arbitara Međunarodnog vijeća sportske arbitraže. ${ }^{32}$ Komisija za sporna pitanja odbila je zahtjev Sportaša kao neosnovan.

\subsubsection{Prigovor presumiranog povlačenja}

Prije formiranja arbitražnog vijeća Sportaš je podneskom iznio prigovor prekluzije, tj. da bi žalitelju (WADA-i) 20. ožujka 2019. istekao rok za podnošenje Obrazloženja žalbenih navoda ${ }^{33}$ zbog čega se ima primijeniti predmnjeva o povlačenju žalbe iz čl. R51. st. 1. Pravilnika CAS-a, ili (eventualno) da bi Vijeće trebalo odbiti Obrazloženje žalbenih navoda kao nepravodobno. Ured Arbitražnog suda $^{34} \mathrm{u}$ ime Predsjednika žalbenog odjela obavijestio je stranke da će o navedenom prigovoru odlučiti arbitražno vijeće nakon formiranja, te je odbio zahtjev Sportaša i FINA-e da se postupci razdvoje.

\subsubsection{Prethodna pitanja}

Sportaš je nakon formiranja Arbitražnog vijeća istaknuo dva pitanja za koja je smatrao da ih treba raspraviti prije upuštanja u raspravu o meritumu spora, odnosno prije podnošenja odgovora na žalbu. Prvo je pitanje dopuštenosti žalbe i nadležnosti CAS-a u pogledu (ne)poštovanja žalbenog roka od strane WADA-e, a drugo je pitanje dopuštenosti žalbe i nadležnosti CAS-a u kontekstu povlačenja WADA-inog pravnog savjetnika iz slučaja zbog sukoba interesa.

Abitražno vijeće odbilo je kao neosnovan prigovor nepravovremenosti Izjave o žalbi i Obrazloženja žalbenih navoda WADA-e, zbog čega je odbilo i zahtjev da se razdvoji odlučivanje (o meritumu i o prigovoru nepravovremenosti) kao nesvrsishodan, te obavijestilo stranke da će razloge takve odluke iznijeti u obrazloženju Pravorijeka. Što se tiče sukoba interesa WADA-inog pravnog

30 Eng. Statement of Appeal.

31 CAS Code of Sports-related Arbitration, izd. 2019. (dalje: Pravilnik CAS-a).

32 Eng. Challenge Commission of the International Council of Arbitration for Sport (dalje: Komisija za sporna imenovanja).

33 Eng. Appeal Brief.

34 Eng. CAS Court Office. 
savjetnika, arbitražno je vijeće o navedenom pitanju odlučilo odlučivati u kasnijem tijeku postupka. ${ }^{35}$

Naknadno je prigovor Sportaša o navodnom sukobu interesa WADA-inog pravnog zastupnika odbijen kao neosnovan, uz obrazloženje da Sportaš (kao osoba na kojoj je teret dokaza) nije dokazao da bi pravni zastupnik WADA-e, kao osoba koja je prethodno bila član Odbora za pravna pitanja FINA-e (kontrastrane ovdje), stekla bilo kakva materijalnopravna ili procesnopravna saznanja koja bi mu mogla koristiti u ovom predmetu, pa time činjenica što navedena osoba sada zastupa WADA-u, u ovom slučaju ne ugrožava procesno načelo jednakosti oružja. S obzirom na navedeno, Arbitražno je vijeće zaključilo da dopuštenost žalbe i nadležnost CAS-a nije dovedena u pitanje. ${ }^{36}$

\subsubsection{Drugi prigovor imenovanja Arbitra i zahtjev za zastojem postupka}

Sportaš je još jednom podnio zahtjev za opozivom imenovanog arbitra Michaela J. Beloffa, navodeći da raspolaže dodatnim informacijama koje nije imao u trenutku donošenja odluke o prvom zahtjevu. Sportaš je dodatno zahtijevao i da se prekine s odlučivanjemu ovoj pravnoj stvari do konačne odluke Komisije za sporna imenovanja i Pravorijeka CAS-a u postupku u kojem se navodno raspravlja o sličnom pravnom pitanju, kao i u postupku koji je Sportaš u međuvremenu pokrenuo pred Švicarskim federalnim sudom radi: 1) poništaja prve Odluke o prigovoru imenovanja arbitra; te 2) poništaja Odluke o pravovremenosti Izjave o žalbi i Obrazloženja žalbenih navoda WADA-e. ${ }^{37}$

Arbitražno vijeće odbilo je zahtjev Sportaša za prekid postupka, uz obrazloženje da ishod bilo kojeg drugog postupka pred CAS-om nije obvezujući za ovo Vijeće, prema činjenicama koje proizlaze iz ovog konkretnog postupka, pri čemu nije na odmet spomenuti kako nije izgledno kada će taj drugi, navodno referentni, postupak pred CAS-om biti okončan, slijedom čega da nije oportuno odgađati odlučivanje u ovom predmetu za neodredivi vremenski period. Arbitražno je vijeće također odbilo i zahtjev Sportaša za prekid ovog postupka do odluke Švicarskog federalnog suda o zahtjevu za poništaj prethodno citiranih odluka, uz napomenu da je navedenu odluku spremno preispitati samo po drugačijoj uputi Švicarskog federalnog suda, dok je drugi prigovor protiv imenovanog arbitra Michaela J. Beloffa proslijedilo na odlučivanje Komisiji za sporna imenovanja, otklonivši svoju nadležnost za odlučivanje o tom pitanju. ${ }^{38}$

Međutim, prije bilo kakve odluke o drugom prigovoru na imenovanog Arbitra g. Michaela J. Beloffa, isti je samostalno odlučio odstupiti iz Vijeća, sve kako bi se osiguralo efikasno odlučivanje u predmetu. Za novog arbitra, WADA je imenovala g. Romana F. Subiotta, odvjetnika u Bruxellesu, Belgija, no Sportaš je istaknuo

\footnotetext{
WADA v. Sun Yang i dr., op. cit., str. 11-12.

Ibid., str. 15-16.

Ibid., str. 12 .

Ibid., str. 13.
} 
prigovor i na novoimenovanog arbitra po prijedlogu WADA-e, koji je komisija za sporna imenovanja odbila kao neosnovan.

\subsubsection{Zahtjev za javno saslušanje}

Još jedna posebnost ovoga postupka odnosi se na javno saslušanje koje je Sportaš predložio da se provede, sve sukladno čl. R57. Zakonika CAS-a, s čim su se složile sve stranke u postupku.

\subsubsection{Dokazni postupak}

Slijedom činjenice da su doping kontrolori IDTM-a (uglavnom) kao svjedoci u ovom postupku izrazili zabrinutost mogućnošću saslušanja na ročištu u sjedištu arbitražnog suda u Lausannei, Arbitražno vijeće je odlučilo: Dopinšku kontrolorku saslušati uzimanjem iskaza na lokaciji u Europi koja će biti naknadno određena (naknadno je određena lokacija Stockholm), Asistenta dopinške kontrolorke saslušati na ročištu - osobno ili putem video/telefonske veze, dok je u pogledu Asistentice za uzimanje uzorka krvi, koja nije izrazila spremnost biti saslušana na bilo koji način, Arbitražno vijeće odlučilo razmotriti njezinu prethodno dostavljenu pisanu izjavu, sukladno čl. R44.1 Pravilnika CAS-a, bez automatskog zauzimanja stava o vjerodostojnosti navedene izjave, a sve zbog činjenice što stranke neće imati mogućnost ispitati svjedoka o navodima iz Izjave.

Naknadno je Asistentica za uzimanje uzorka krvi ipak pristala biti saslušana uzimanjem iskaza putem videokonferencije održane u Lausannei, kojoj su prisustvovali zastupnici stranaka i Arbitražno vijeće. S druge strane, Asistent dopinške kontrolorke je promijenio stav o spremnosti da bude saslušan na ročištu, te dostavio svoj pisani iskaz, a neposredno pred ročište po treći se put predomislio i pristao biti saslušan no pod određenim uvjetima. Kako Arbitražno vijeće u tom trenutku više nije bilo sklono mijenjati dinamiku održavanja ročišta, u konačnici je odlučeno ne saslušati Asistenta dopinške kontrolorke, već primiti na znanje njegov pisani iskaz. ${ }^{39}$ Ambivalentnost ključnih svjedoka može se dovesti u vezu s brojnim upozorenjima WADA-e da suprotna strana nastoji stupiti u kontakt sa svjedocima, koji kontakti idu do razine prijetnje, zbog čega je u više navrata tijekom postupka WADA tražila i izdavanje privremene mjere kojom bi se strankama zabranilo vršiti bilo kakav kontakt sa svjedocima izvan suda.

U konačnici, 15. studenog 2019. održano je ročište u Montreuxu, Švicarska, koje je bilo javno emitirano na internetu i na kojem su saslušani Sportaš; g. Stuart Kemp - zamjenik direktora WADA-e za usklađenost i standard (na prijedlog WADA-e); g. Tudor Popa - IDTM-ov koordinator testiranja (na prijedlog WADA-e); g. Neal Soderstrom - IDTM-ov direktor za odnose s klijentima i razvoj poslovanja (na prijedlog WADA-e); gđa. Ming Yang - Sportaševa majka (na prijedlog Sportaša); dr. Ba Zhen - Sportašev liječnik (na prijedlog Sportaša); dr. Han Zhaoqi - glavni

\footnotetext{
39 Ibid., str. 24.
} 
doktor u ustanovi gdje dr. Ba Zhen radi, te glavni doktor u bolnici povezanoj sa sportskim fakultetom Zhejiang (na prijedlog Sportaša); g. Cheng Hao - direktor kineske plivačke reprezentacije (na prijedlog Sportaša); prof. Pei Yang, te docent na Pravnom fakultetu Sveučilišta Beijing Normal (kao ekspert na prijedlog Sportaša). ${ }^{40}$

\subsubsection{Odluka o nadležnosti kao prethodnom pitanju}

U odnosu na prigovor nadležnosti arbitražnog vijeća CAS-a, Pravorijekom se ukazuje na primjenjive odredbe Pravilnika CAS-a, prema kojima CAS može odlučivati kao drugostupanjski sud, ako je u referentni akt sportske federacije takva klauzula uvrštena. U konkrentom slučaju Pravila FINA-e sadrže odredbu prema kojoj je moguće CAS-u uputiti žalbu na Odluku Federacije u predmetima vezanima za povredu pravila o antidopingu, pod uvjetom da se radi o sportašu međunarodnog ranga. Budući da je u ovom slučaju nesporno da je Sportaš međunarodnog ranga, nadležnost CAS-a da odlučuje nije dovedena u pitanje. Samim time, prigovori Sportaša da WADA nije poštovala vremenski rok za podnošenje žalbe, i to zbog navodnog sukoba interesa WADA-inih pravnih savjetnika, ne mogu se smatrati prigovorom nadležnosti CAS-a da odlučuje u predmetu, već isključivo prigovorom prekludiranosti žalitelja da podnese žalbu arbitražnom sudu. ${ }^{41}$

\subsubsection{Odluka o dopuštenosti (pravovremenosti) WADA-ine žalbe kao prethodnom pitanju}

U svibnju 2019. Ured Arbitražnog suda obavijestio je stranke da je Arbitražno vijeće odbilo Sportašev prigovor nedopuštenosti (nepravovremenosti) žalbe o čemu će razloge iznijeti u Pravorijeku. U obrazloženju Pravorijeka, Arbitražno vijeće prije svega se referiralo na nesporne činjenice:

i) Kineska nacionalna antidopinška agencija ${ }^{42}$ imala je također pravo osporavati Odluku Antidopinškog vijeća FINA-e od 3. siječnja 2019., i to kao Sportaševa matična antidopinška organizacija prema čl. 13.2.3.d Pravila FINA-e..$^{43}$ Budući da je CHINADA-i sporna odluka dostavljena 7. siječnja 2019., prema čl. 13.7.1. točki 1. Pravila FINA-e, istoj organizaciji dvadeset i jednodnevni rok za pobijanje navedene odluke istekao je 28. siječnja 2019.;

ii) Nije sporno niti da je FINA prema točki 3. istog članka, imala dodatni dvadeset i jednodnevni rok za pobijanje sporne odluke, koji je istekao 18. veljače 2019., odnosno 21 dan nakon što je rok istekao CHINADA-i;

Međutim, ono što je ostalo sporno, te bilo predmetom Sportaševog prigovora, jest pitanje računa li se WADA-i rok za podnošenje Izjave o žalbi jednako kao i

40 Ibid.

41 Ibid., str. 35-36.

42 Eng. China Anti-Doping Agency (dalje u tekstu: CHINADA).

43 „U slučajevima iz čl. 13.2.1. Pravila FINA-e, pravo na žalbu CAS-u imaju slijedeće stranke: ... d) Nacionalna Antidopinška organizacija zemlje sportaševa prebivališta ili državljanstva ili zemlje koja mu je izdala licencu; ..." 
FINA-i, ili WADA ima dodatnih 21 dan po isteku FINA-inog roka, za podnošenje Izjave o žalbi? ${ }^{44}$

Arbitražno vijeće je o navednom pitanju zauzelo stav da prema članku 13.7.1. točka 2(a) Pravila FINA-e, WADA-in rok za podnošenje Izjave o žalbi na spornu odluku istječe 21 dan nakon ,zadnjeg dana kada bi bilo koja druga stranka u navedenom predmetu mogla izjaviti žalbu”, pri čemu su riječi „bilo koja druga stranka" primjenjive i na FINA-u, slijedom čega WADA ima dodatni period od 21 dana za podnošenje Izjave o žalbi, i to nakon što FINA-i istekne rok za podnošenje Izjave o žalbi. Kao razlog navedenom, Arbitražno vijeće je istaknulo činjenicu da je funkcija WADA-e usklađivanje primjene Pravilnika WADA-e, shodno čemu mora biti u mogućnosti donijeti odluku o podnošenju Izjave o žalbi nakon što su joj sve relevantne informacije na raspolaganju, a što proizlazi kako iz članka 13.2.3 Pravilnika WADA-e, tako i iz članka 13.7.1. točke 2(a) Pravila FINA-e, te ukoliko bi FINA-i bio omogućen usporedni vremenski rok za podnošenje Izjave o žalbi, smisao prethodnih članaka bio bi narušen, jer bi WADA morala donijeti odluku o podnošenju Izjave o žalbi bez znanja o tome hoće li uopće FINA podnijeti Izjavu o žalbi. ${ }^{45}$

Slijedom navedenog, kako je FINA-i rok za podnošenje Izjave o žalbi istjecao 18. veljače 2019., WADA je imala dodatnih 21 dan za podnošenje svoje Izjave o žalbi, tj. do 11. ožujka 2019., dok joj je rok za podnošenje Obrazloženja žalbe istjecao 21. ožujka 2019., odnosno 10 dana nakon isteka roka za podnošenje Izjave o žalbi. Međutim, kako je WADA-i po traženju omogućeno dodatnih 20 dana, rok za podnošenje Obrazloženja žalbe istekao je tek 10. travnja 2019., a s obzirom na to da je WADA Obrazloženje žalbe podnijela 3. travnja 2019., isto je nesporno bilo pravovremeno, te je Sportašev prigovor nepravovremenosti WADA-ine žalbe odbijen kao neosnovan. ${ }^{46}$

\subsubsection{Odluka o bitnim činjenicama u predmetu}

\subsubsection{Je li Sportaš prekršio antidopinška pravila?}

Člankak 2.5 Pravila FINA-e - Utjecanje ili pokušaj utjecanja na postupak doping kontrole, podrazumijeva bilo kakvo ponašanje koje podriva dopinšku kontrolu, ali koje inače ne bi bilo definirano kao Zabranjena metoda u kontekstu dopinga. Utjecanje uključuje, primjerice, namjerno upletanje ili pokušaj upletanja u rad Doping kontrolora, pružanje lažnih podataka antidopinškoj organizaciji, odnosno zastrašivanje ili pokušaj zastrašivanja potencijalnog svjedoka.

Pojam Dopinška kontrola definiran je u Dodatku 1 Pravila FINA-e i označava „sve korake i procese, od planiranja testiranja do konačne odluke o žalbama, uključujući sve korake i procese između tih faza, poput pružanja informacija o

\footnotetext{
44 WADA v. Sun Yang i dr., op. cit., str. 41-42.

45 Ibid., str. 42.

46 Ibid.
} 
lokaciji, sakupljanju i rukovanju s uzorcima, laboratorijske analize, izuzeća zbog terapijske uporabe, upravljanja rezultatima i saslušanja."

Pojam Utjecanje također je definiran u Dodatku 1 Pravila FINA-e i označava „mijenjanje u neprimjerenu svrhu ili na neprimjeren način; nepropisni utjecaj ili miješanje; opstruiranje, dovođenje u zabludu ili prijevarno postupanje u svrhu mijenjanja rezultata ili sprečavanja redovnih postupaka."

Sportaš je nesporno naložio uništenje spremnika krvi, te uništio obrazac dopinške kontrole koji je prethodno bio potpisao, zbog čega je kontrolor bio onemogućen sakupiti uzorke krvi i urina. Argumenti koje je Sportaš iznio u ovom postupku, razlikuju se od navoda iz izjave koju je dr. Ba Zhen sastavio u noći sa 4. na 5. rujna 2018. Vijeće ne dvoji da postupci Sportaša predstavljaju opstrukciju postupka prikupljanja uzoraka, i to iz razloga jer je isti spriječio kontrolora da odnese uzorke krvi na analizu, čime je prekršio članak 2.5 Pravila FINA-e. S druge strane, Sportaš nije ponudio uvjerljivo obrazloženje ${ }^{47}$ koje bi mu omogućilo postupiti s ciljem sprečavanja postupka dopinške kontrole. Praksa CAS-a u primjeni pravila dopinške kontrole je takva da se ,nalaže i očekuje od sportaša da daju uzorak kada god je to fizički, higijenski i moralno moguće, bez obzira na postojanje prigovora od strane sportaša, a ukoliko se to propusti, smatrat cee se da su sportaši odbili dati uzorak i time onemogućili testiranje." ${ }^{48}$ Dakle, u odnosu na konkretan slučaj bitno je napomenuti da nikada nije dozvoljeno sportašu ,uzeti pravdu u svoje ruke”, dok u samo krajnje izuzetnim slučajevima propuštanja notificiranja sportaša o postupku uzimanja uzoraka ne bi bilo primjereno provesti postupak dopinške kontrole. Samim time, Sportaš se trebao podvrgnuti postupku testiranja u potpunosti, ali i istaknuti bilo kakav prigovor na zapisnik ili kasnije (čim prije). ${ }^{49}$

Što se tiče Sportaševog prigovora da o postupku testiranja nije propisno obaviješten, odnosno da mu IDTM-ovi kontrolori nisu prezentirali autorizaciju za provođenje postupka, koja bi sadržavala imena kontrolora, Arbitražno vijeće smatra da je prije svega, u kontekstu primjenjive odredbe čl. 5.3.3 ISTI-a, ${ }^{50}$ bitno razlučiti kako FINA predstavlja tijelo nadležno za testiranje, ${ }^{51}$ a IDTM tijelo koje (faktično) provodi testiranje, tj. postupak uzimanja uzoraka. ${ }^{52}$ Nastavno navedenoj odredbi, odlučeno je da je neosnovan prigovor Sportaša da su kontrolori IDTM-a prema primjenjivim odredbama ISTI-ja njemu trebali predočiti i pismo kojim su

47 Eng. compelling justification, pojam koji prema čl. 2.3 Pravila FINA-e označava valjano opravdanje zbog propuštanja, izbjegavanja ili odbijanja davanja uzorka.

48 CAS 2005/A/925, Laura Dutra de Abreu Mancini de Azevedo v. FINA, Pravorijek od 24. I. 2006. para. 75 (dalje: slučaj Azevedo); Isto vidjeti pravorijeke br. CAS 2012/A/2791, CAS 2013/A/3077, CAS 2013/A/3342 i CAS 2016/A/4631.

49 WADA v. Sun Yang i dr., op. cit., str. 47-48.

50 „U svrhu dokazivanja svojstva ovlaštenih službenika za uzimanje uzoraka, navedeni službenici moraju imati službenu dokumentaciju Tijela koje provodi postupak uzimanja uzoraka, primjerice autorizacijsko pismo Tijela nadležnog za testiranje. Dopinški kontrolori će imati i identifikaciju sa svojim imenom, fotografijom i rokom važenja iste ( $\mathrm{tj}$. iskaznicu Tijela koje provodi postupak uzimanja uzoraka, vozačku dozvolu, zdravstvenu iskaznicu, putovnicu ili drugu važeću identifikacijsku ispravu).“

51 Eng. Testing Authority.

52 Eng. Sample Collection Authority. 
ti kontrolori poimence ovlašteni od Tijela nadležnog za testiranje, jer iz citirane odredbe ISTI-ja proizlazi da je dostatno predočiti (generičko) pismo kojim FINA, kao tijelo nadležno za testiranje, za prikupljanje uzoraka ovlašćuje IDTM (u kojem pismu je navedeno i ime glavnog dopinškog kontrolora). Također, među strankama je nesporna činjenica da je od ukupno 180 antidopinških kontrola Sportaša u periodu od 2012. do 2019., IDTM izvršio 60, pri čemu Sportaš ničime nije dokazao da bi bilo koja od navedenih 60 kontrola u formi postupanja odudarala od ovog, spornog postupanja, što također utječe na vjerodostojnost Sportaševih navoda. ${ }^{53}$ Nadalje, što se tiče prigovora da bi generičko ovlaštenje FINA-e nužno trebalo sadržavati i imena Asistenta dopinške kontrolorke i Asistentice za uzimanje uzorka krvi, a sve zbog formulacije čl. 5.3.3 ISTI-a, gdje stoji da „u svrhu dokazivanja svojstva ovlašenih službenika za uzimanje uzoraka, navedeni službenici moraju imati ...", Arbitražno vijeće je - nakon utvrđenja da je glavna dopinška kontrolorka osobno osposobila Asistenta za uzimanje uzorka urina i Asistenticu za uzimanje uzorka krvi, što je formalizirano njihovim potpisom „Izjave o povjerljivosti”, koja je sadržana na IDTM-ovom memorandumu i pohranjena u IDTM-ovom arhivu utvrdilo ispravnost takvog postupanja, što je u konačnici potvrdio i svjedok, g. Kemp, koji je od 2009. u timu ljudi koji sastavlja propise ISTI-ja i koji je naveo da se zadatak imenovanja asistenata obično delegira, pa samim time nedostatak imena asistenata u generičkom ovlaštenju nije zapreka njihovu sudjelovanju u testiranju ako su osposobljeni za navedeni zadatak. ${ }^{54}$

Što se tiče Sportaševog prigovora da mu se pri provođenju postupka (svi) IDTM-ovi kontrolori nisu propisno identificirali (tj. legitimirali), Arbitražno vijeće utvrdilo je upravo suprotno, tj. da su glavna dopinška kontrolorka, asistent dopinške kontrolorke i asistentica za uzimanje uzorka krvi postupili prema svim standardima notificiranja testirane osobe propisanima ISTI-jem. Arbitražno vijeće dodatno napominje da je nakon inicijalne legitimacije kontrolora IDTM-a, a prije spornog fotografiranja, Sportaš potpisao i Obrazac dopinške kontrole. Navedeno je bitno zbog članka 5.4.3 ISTI-ja, u kojem je navedeno: „Pratitelj uzimanja uzorka/ Dopinški kontrolor će tražiti od sportaša da potpiše obrazac kojim prima na znanje i prihvaća obavijest. Ukoliko Sportaš odbije potpisati da je obaviješten, ili izbjegava primitak obavijesti, utoliko će Pratitelj uzimanja uzorka/Dopinški kontrolor, ako je moguće, obavijestiti Sportaša o posljedicama odbijanja ili propuštanja postupanja, a ako Pratitelj uzimanja uzorka nije ujedno i Dopinški kontrolor, o svim relevantnim činjenicama će obavijestiti Dopinškog kontrolora. Čim postane moguće, Dopinški kontrolor će nastaviti prikupljati uzorke. Dopinški kontrolor će navesti sve činjenice u detaljnom izvješću koje će dostaviti Tijelu nadležnom za testiranje, koje će pak u postupanju slijediti korake propisane Dodatkom A Istraga potencijalnog propuštanja u postupanju po nalogu." Potpisom na Obrascu dopinške kontrole Sportaš je de facto primio na znanje i prihvatio činjenicu da je bio propisno obaviješten, a tek naknadno (potaknut drugim događajima, nevezanim za

53 WADA v. Sun Yang i dr., op. cit., str. 49-50, 53.

54 Ibid., str. 54-55. 
legitimiranje) poderao je već potpisani obrazac, iz čega Arbitražno vijeće zaključuje da je do toga spornog trenutka, Sportaš smatrao valjanim, kako proces legitimacije, tako i dokumentaciju koja mu je predočena..$^{55}$

\subsubsection{Je li Sportaš imao drugi (valjani) razlog odbiti postupak prikupljanja uzoraka?}

Budući da je Asistent dopinške kontrolorke bio jedini muški član među kontrolorima IDTM-a, nije bilo moguće provesti postupak uzimanja urina od Sportaša. Kako je u postupku dokazano da je prijedlog Sportaša bio pričekati dolazak drugog asistenta za uzimanje uzorka urina, ne može se dovesti u pitanje njegova spremnost dati uzorak urina. Međutim, u pogledu uzimanja uzorka krvi, okolnost što je asistent dopinške kontrolorke neprimjereno fotografirao Sportaša, nije opravdani razlog za uskraćivanje pristanka na daljnje testiranje, a pogotovo ne opravdava Sportaševe daljnje radnje (sprečavanje kontrolora da napuste mjesto testiranja, uništavanje posude s uzorkom krvi i uništavan ${ }_{s}$ je obrasca dopinške kontrole). Nadalje, u pogledu spornog navoda Sportaša da ga kontrolori nisu obavijestili o posljedicama nepostupanja po zahtjevu za provođenjem dopinške kontrole (tj. da je jednostrano okončanje testiranja od strane igrača plod nesporazuma i neshvaćanja posljedica istog, a ne namjerne radnje), Arbitražno vijeće je sagledavši sve dokaze u postupku utvrdilo da nije postojala ispričiva okolnost u vidu nedostaka upozorenja o posljedicama nepostupanja po nalogu kontrolora. Dopinška kontrolorka je višestruko upozorovala ili barem pokušala upozoriti Sportaša o potencijalnim posljedicama nepostupanja, do kojeg zaključka je u konačnici došlo i Dopinško vijeće FINA-e. ${ }^{56}$ Arbitražno vijeće se složilo s Dopinškim vijećem FINA-e da su se takva upozorenja mogla i ne čuti u cijeloj buci, no suprotno stavu Dopinškog vijeća FINA-e, Arbitražno vijeće smatra da bi takva okolnost (čak i da je točna) bila isključivo posljedica radnji i postupaka Sportaša, koji je svakako trebao poštovati autoritet Dopinške kontrolorke. Arbitražno vijeće nije imalo razloga ne vjerovati iskazima Dopinške kontrolorke, te Asistentice za uzimanje uzoraka krvi, koje su iskazivale da je Dopinška kontrolorka višestruko upozoravala Sportaša o mogućim posljedicama njegovih radnji. Također, g. Cheng Hao je u svojoj pisanoj izjavi naveo kako je ,posebno napomenuo Dopinškoj kontrolorki da ne bi trebalo koristiti riječ odbijanje, i to iz razloga jer je ranije te godine kontrolor CHINADA-e upitao jednog sportaša - želiš li reći da odbijaš testiranje - zbog čega je dobio otkaz, jer je stav CHINADA-e bio da se radi o sugestivnom pitanju", što je Arbitražno vijeće protumačilo kao raspravu koja je uslijedila nakon što je Dopinška kontrolorka spomenula potencijalne posljedice nepostupanja. U konačnici, i g. Popa je iskazivao kako je te večeri bio u kontinuiranoj telefonskoj vezi s Dopinškom kontrolorkom, te je čuo kada je upozorila Sportaša o posljedicama nepostupanja po nalogu. Sve to

55 Ibid., str. 61-62.

56 „Sasvim je jasno da je Dopinška kontrolorka kontinuirano pokušavala objasniti zašto su prigovori i manjkavosti koje spominje Sportaš neosnovani po njenom mišljenju.“ 
ukazuje da je zaključak Dopinškog vijeća FINA-e tj. pobijana odluka, trebala biti drugačija. ${ }^{57}$

Arbitražno je vijeće zauzelo stav da je jednako neuvjerljiv bio i pokušaj Sportaša da krivnju prebaci na svoj tim asistenata, kada je tijekom saslušanja iskazivao da su ga upravo oni savjetovali da postupi na način kako je postupio. Čak i da je istina da se u dobroj vjeri oslanjao na savjete svojega tima, posebice u vezi s akreditacijama, autorizacijom i osobama koje su prisustvovale testiranju, Sportaš je bio vrlo iskusan u ovoj vrsti postupaka, te je isključivo on donio odluku da se postupak uzimanja krvi prekine, unatoč nastojanju Dopinške kontrolorke da uzorke krvi odnese na testiranje. Uostalom, već je poprilično ustaljena praksa CAS-a da sportaši ne mogu prebaciti odgovornost na svoj tim asistenata, čak ni u ekstremnim situcijama gdje članovi tima asistenata prijete sportašima $\mathrm{s}$ određenim posljedicama ukoliko ne poslušaju njihove upute. U prilog prethodne tvrdnje, Arbitražno vijeće ukazalo je na sljedeću sentencu sudske odluke: „Općenito govoreći, Arbitražno vijeće je zaključilo da činjenica što je sportaš osjećao obvezu izbjeći antidopinško testiranje zbog uputa trenera i/ili menadžera i/ili drugog člana njegovog/njezinog tima i/ili službenika čiji autoritet sportaš obično mora poštovati pod prijetnjom da će bilo kakav neposluh rezultirati uskraćivanjem prava na normalno treniranje i natjecanje - u načelu se ne mogu smatrati uvjerljivim opravdanjem, jer sportaš nacionalnog ili međunarodnog ranga obično ima mogućnosti zbog kojih bi trebao preuzeti odgovornost i zanemariti takve prijetnje. Antidopinški sustav koji je normiran Pravilnikom Svjetske antidopinške agencije, zasnovan je na načelu osobne odgovornosti sportaša, te obuhvaća i obvezu poznavanja antidopinških pravila i suprotstavljanja pritiscima da ih se krši. Ukoliko se ova pravila osobne odgovornosti sportaša ne bi strogo provodila, utoliko bi bila ostavljena mogućnost osobama u njihovoj pratnji i/ili nepoštenim službenicima da pokušaju vršiti pritisak na sportaše i ograničavati njihovu slobodu, a također bi moglo potaknuti beskrupulozne sportaše da pokušaju iskoristiti članove svojeg tima ili druge osobe kao žrtvene janjce." ${ }^{58}$ Kao još jedan argument u korist svojeg zaključka, Arbitražno vijeće ukazuje i na Odluku britanske antidopinške agencije, u predmetu Rugby Football Union v. McIntosh, posl. br. SR/NADP/782/2017, gdje je Sportaš osuđen za utjecanje na postupak testiranja, i to iz razloga jer je povukao svoj pristanak na davanje uzorka urina koji je već bio dao, pod obrazloženjem da je u mirovini. Suprotno Sportaševu viđenju navedene presude, Arbitražno vijeće ne smatra citirani predmet fundamentalno različitim od ovog predmeta - gdje je Sportaš dao uzorak krvi, a potom povukao svoj pristanak iz razloga koje Arbitražno vijeće ne smatra uvjerljivim, sve uz otegotnu okolnost što je i uništio spremnik s krvnom posudicom, te pocijepao Obrazac dopinške kontrole, čime je u konačnici prekršio članak 2.5 Pravila FINA-e. ${ }^{99}$

57 WADA v. Sun Yang i dr., op. cit., str. 64-66.

58 CAS 2012/A/2791, WADA v. Malaysia Athletic Federation, Jumaludin et al., Pravorijek od 24. V. 2013.

59 WADA v. Sun Yang i dr., op. cit., str. 70-71. 


\subsubsection{Odluka o sankciji}

Arbitražno vijeće pravorijek u ovom predmetu donijelo je 20. veljače 2020., kojim je:

1) žalba WADA-e od 14. veljače 2019. protiv Odluke Dopinškog vijeća FINA-e od 3. siječnja 2019. usvojena;

2) Odluka Dopinškog vijeća FINA-e od 3. siječnja 2019. ukinuta; te

3) Sportaš g. Sun Yang kažnjen s periodom nepodobnosti od osam godina, počevši od dana donošenja Pravorijeka ...

Prema čl. 10.3.1 Pravila FINA-e period nepodobnosti zbog povrede čl. 2.3 ili 2.5 Pravila FINA-e bit će četiri godine, osim ako sportaš uspije dokazati da povreda antidopinških pravila nije učinjena s namjerom, u kojem će slučaju period nepodobnosti biti dvije godine. U konkretnom je slučaju Arbitražno vijeće utvrdilo da je Sportaš prekršio čl. 2.5 Pravila FINA-e, na što se primjenjuje četverogodišnji period nepodobnosti, osim ako se ne utvrdi primjenjivost članaka 10.5 (Smanjenje perioda nepodobnosti zbog izostanka namjere ili krajnje nepažnje) ili 10.6 (Brisanje, smanjenje ili suspenzija perioda nepodobnosti ili drugih posljedica zbog ostalih razloga izuzev krivnje) Pravila FINA-e. ${ }^{60}$

Nesporno je da Sportaš nije pomogao u otkrivanju ili utvrđenju povrede antidopinških pravila, odnosno priznao isto, pa se članak 10.6 Pravila FINA-e ne može primijeniti. Budući da je namjera element članka 2.5 Pravila FINA-e, koncept izostanka namjere ili krajnje nepažnje u ovom slučaju nije primjenjiv. Slijedom svega, zaključeno je da smanjenje sankcije ispod četiri godine nepodobnosti nije moguće. Uz istaknuto, Vijeće se posebno osvrnulo na ponašanje Sportaša tijekom samog postupka pred CAS-om, tj. pri završnom govoru kada je u nastojanju da demonstrira događaje iz sporne noći samoinicijativno pozvao osobu koja je kao javnost prisustvovala suđenju da glumi kontrolora. Osim toga, Sportaš je do samog kraja suđenja isticao isključivo formalne prigovore na postupak, dok niti jednom riječju nije izrazio žaljenje u odnosu na svoje nasilno postupanje u vrijeme spornog događaja. ${ }^{61}$

Kako je Sportaš već 2014. kažnjen s tromjesečnim rokom nepodobnosti, ovo predstavlja njegov drugi prekršaj članka 2.5 Pravila FINA-e, pa se sukladno članku 10.7.1(c) Pravila FINA-e izrečena kazna četverogodišnje nepodobnosti ima računati u dvostrukoj visini, odnosno u ukupnom iznosu od osam godina. ${ }^{62}$

WADA je nadalje zahtijevala da se Sportaša kazni i oduzimanjem svih medalja, bodova ili nagrada koje je isti ostvario od 4. rujna 2018. (dana spornog testiranja) do dana odpočinjanja izrečenog perioda nepodobnosti, sve sukladno članku 10.8

\footnotetext{
60 Ibid.

61 Ibid., str. 72-73.

62 Ibid., str. 75 .
} 
Pravila FINA-e, ${ }^{63}$ no Sud je, primjenivši načelo pravičnosti, posebno u kontekstu izrečene zaista drastične kazne od osam (8) godina nepodobnosti, zaključio da dodatno kažnjavanje nije potrebno. Navedenu procjenu Sud je donio uvažavajući okolnost da je u kritičnom periodu Sportaš postao svjetski prvak slobodnim stilom na 200 m i 400 m na Svjetskom prvenstvu u Gwangju, Južnoj Koreji, kada je bio podvrgnut dopinškim testiranjima (15., 19., 20., 21. i 24. kolovoza, te 28. rujna 2018), koji su svi bili negativni. Uostalom, i sporno dopinško testiranje 4. rujna 2018. nije pokazalo pozitivan rezultat, već je ponašanje Sportaša bila okolnost presumpcije za aktiviranje odredbe o nepodobnosti. Konačan argument, koji je Sud pri odlučivanju uzeo u obzir, jest činjenica da FINA nikada nije tražila određivanje privremene mjere kojom bi se Sportašu zabranilo daljnje nastupanje na natjecanjima u periodu dok postupak pred CAS-om traje. ${ }^{64}$

\section{STANDARD DOKAZIVANJA}

\subsection{Utjecanje ili pokušaj utjecanja na postupak doping kontrole}

Kao što je prikazano u obrazloženju predmeta Sun Yang, inkriminacija Sportaša bazirana je na članku 2.5 Pravila FINA-e, koji članak je de facto implementirani članak 2.5 Pravilnika Svjetske antidopinške organizacije (WADA-e), naziva Utjecanje ili pokušaj utjecanja na postupak doping kontrole. ${ }^{65}$ Bitan element referentnog članka opisan je pojmom „utjecanje” koje obuhvaća primjere zbirno navedenih vrsta izravnih ili neizravnih radnji testirane osobe (,primjerice, namjerno upletanje ili pokušaj upletanja u rad Doping kontrolora, pružanje lažnih podataka antidopinškoj organizaciji, odnosno zastrašivanje ili pokušaj zastrašivanja potencijalnog svjedoka"), koje ovlašteni tužitelj mora dokazati na razini poprilične izvjesnosti kako bi propisana sankcija bila primjenjiva. ${ }^{66}$ Ova odredba uperena je na ponašanje sportaša koje podriva postupak dopinške kontrole, ali inače nije uvršteno u listu, odnosno definiciju zabranjenih metoda. Dakle, lista nije konkretizirana, pa su stoga brojni primjeri koji potpadaju pod navedenu definiciju, od razbijanja bočica

63 „Uz automatsku diskvalifikaciju rezultata na događaju koji je rezultirao pozitivnim uzorkom prema čl. 9 Pravila, svi drugi rezultati koje Sportaš ostvari od dana kada pozitivni uzorak bude prikupljen (za vrijeme ili izvan natjecanja), ili dana kada drugi antidopinški prekršaj bude utvrđen, do otpočinjanja bilo kakve privremene mjere suspenzije ili perioda nepodobnosti, osim ako prema načelu pravičnosti treba postupiti drugačije, bit će diskvalificirani uz sve ostale posljedice poput oduzimanja medalja, bodova ili nagrada."

64 WADA v. Sun Yang i dr., op. cit., str. 75-76.

65 Na web-stranicama Hrvatskog zavoda za javno zdravstvo, u službenom prijevodu Pravilnika za borbu protiv dopinga za članak 2.5 korišten je naziv „Krivotvorenje ili pokušaj krivotvorenja bilo kojeg dijela dopinške kontrole“, dok je u Prilogu 1 Pravilnika pojam „krivotvorenje“ definiran kao „mijenjanje za neprimjerenu svrhu ili na neprimjeren način; neprilično utjecanje; neprilično upletanje; ometanje, navođenje na krivi trag ili upuštanje u bilo kakve prijevarne radnje zbog mijenjanja rezultata ili sprečavanja provođenja uobičajenih postupaka."“

${ }_{66}$ O teretu dokazivanja i zahtijevanom stupnju vjerojatnosti vidjeti u: Hrvoje Kačer, Blanka Kačer, „(Neke) pravne dvojbe u vezi s dopingom“, u: Hrvoje Kačer et al., Sportsko pravo, Pravni fakultet Sveučilišsta u Splitu, Split, 2018., str. 547. 
s uzorcima za analizu za vrijeme testiranja (kao u predmetu kojim se ovaj rad bavi), do davanja neistinitih podataka organizaciji koja provodi testiranje (primjerice o lokaciji gdje se sportaš nalazi) ili zastrašivanja svjedoka. ${ }^{67}$

\subsection{Primjeri ,utjecanja” na postupak}

U jednom (s obzirom na nabrajanje nazovimo ga prvim) antidopinškom postupku koji se vodio protiv plivačice zbog korištenja zabranjene supstance, ${ }^{68}$ ista je optužena za ,utjecanje” iz razloga što je u urinu koji je plivačica dala na analizu utvrđena razina alkohola (konkretno viskija) koja bi za osobu bila smrtonosna da je zaista unese u svoj organizam, iz čega je organizacija koja je provodila testiranje zaključila da je navedeni uzorak plivačica „fabricirala”, sve u cilju prikrivanja zabranjene supstance (dopinga) koja se nalazi u njezinom organizmu.

U drugom pak slučaju ${ }^{69}$ dizač utega je optužen da bi manipulirao uzorcima urina koje je predao kontrolorima pri testiranju, na način da je, u nekon trenutku prije predaje uzorka, zamijenio svoj uzorak s uzorkom treće osobe, sve kako bi prikrio mogućnost otkrivanja dopinga. Antidopinška organizacija je takav zaključak donijela kada je pri ispitivanju uzoraka više sportaša, kod čak trojice pronašla identičan uzorak, tj. uzorak koji je došao od jedne te iste osobe. Dizač utega je osporavao inkriminaciju, tvrdeći da je nepoznata osoba sabotirala uzorke sportaša na način da je podmetnula isti uzorak u spremnike sve trojice, tako da ne ostavi vidljiva traga na spremnicima. ${ }^{70}$ Teret dokaza bio je na Dizaču utega, koji u postupku nije uspio dokazati da bi bočicu u koju se uzorak pohranjuje netko mogao otvoriti bez

67 Lewis i Taylor, op. cit., str. 529-530.

68 CAS 98/211, Michelle Smith De Bruin v. FINA, Pravorijek od 7. VI. 1999.

69 CAS 2004/A/607, Boevski v. International Weightlifting Federation (IWF), Pravorijek od 6. XII. 2004.

70 Isto tako v. CAS 2016/A/4458, Lisa Christina Nemec v. Hrvatska agencija za toksikologiju i antidoping (HZTA), Pravorijek od 27. IV. 2017., gdje je sportašica nastojala dokazati da je netko od prisutnih kontrolora kontaminirao uzorak urina sportašice, moguće kapljičnim apliciranjem zabranjene supstance u spremik urina koji je jedan vremenski period - zbog događaja na mjestu testiranja, uslijed kojeg sportašica nije imala priliku nadzirati svoj, još uvijek nezapečaćeni, uzorak urina - bio izvan nadzora sportašice. Upravo zbog brojnih nepravilnosti pri provođenju testiranja izvan natjecanja (poput kontrolora koji su najavljeni, a nisu došli, te navodno istrošene baterije u uređaju za mjerenje gustoće i koncentracije urina koju je potrebno promijeniti prije pečaćenja poklopca na bočici s uzorkom - zbog čega je sportašica ostavila kontrolorku bez nadzora s uzorkom da bi u drugoj sobi potražila zamjensku bateriju, za koju se po povratku utvrdilo da nije trebala, jer je uređaj u međuvremenu ,proradio“), te prema mišljenju sportašice financijski i osobno uvjetovanih razloga kod osobe koja je imala pristup zabranjenoj supstanci eritropoetinu i čelnika konkurentskog atletskog kluba (obojica vršitelji određenih djelatnosti kod HZTA-e), postojao je motiv da se sportašici podmetne kontaminirani uzorak. Međutim, arbitražno vijeće u konačnici nije smatralo da argumenti obrane udovoljavaju standardu poprilične izvjesnosti da bi ih usvojilo. Što se tiče tereta dokazivanja Arbitražno vijeće je zauzelo opći stav da ukoliko bi sportaš uspio dokazati odstupanje od ISTI-ja, koje bi vjerojatno moglo biti uzrokom nepovoljnog nalaza, tada se teret dokazivanja da takvo odstupanje nije uzrokovalo nepovoljni nalaz prebacuje na Tijelo koje provodi testiranje. 
ostavljanja vidljivog traga. ${ }^{71}$ Što se tiče standarda dokazivanja, u ovom postupku stranke su ugovorile švicarsko pravo, prema kojem Vijeće, da bi usvojilo određeni zahtjev, mora biti uvjereno u odlučne činjenice na razini poprilične izvjesnosti, ${ }^{72}$ koji je standard dokazivanja veći od vjerojatnosti, ali manji od standarda izvan razumne sumnje.

U trećem pak slučaju ${ }^{73}$, sportaš koji je neposredno prije testiranja osvojio prvo mjesto na natjecanju u skoku u dalj, optužen je da bi utjecao na postupak testiranja, jer je odbio dati uzorak urina koristeći posudicu za koju je smatrao da ima oštećeni omot i poklopac (te time ne udovoljava standardima opreme za testiranje), a koja posudica je bila jedna od ukupno tri posudice koje je dopinški kontrolor imao u svom posjedu, pri čemu su dvije posudice već bile kontaminirane (jedna posudica za prikupljanje uzorka upala je sportašu u WC školjku, a druga posudica na pod Stanice za dopinški pregled). Uz činjenicu što je odbio dati uzorak zbog prethodno opisanog razloga, isto tako nije bio spreman pričekati dolazak osobe s dodatnim posudicama dulje od 30 minuta, već je napustio Stanicu za doping testiranje bez davanja traženog uzorka urina, a sve pod obrazloženjem da je morao ići na aerodrom kako ne bi zakasnio na let. Arbitražno vijeće odlučilo je da sportaš nije ispunio standard valjanog opravdanja u odnosu na sporno postupanje, jer je bilo „fizički, higijenski i moralno moguće dati uzorak urina" ${ }^{\text {"74 }}$, dok je sve eventualne prigovore na postupak mogao iznijeti na zapisnik. Slijedom navedenog, postupanje sportaša kvalificirano je prema standardu poprilične izvjesnosti kao povreda antidopinških pravila - utjecanje ili pokušaj utjecanja na bilo koji dio antidopinške kontrole - i izrečena mu je sankcija.

\section{ZAKLJUČAK}

Iz samo primjerice određenog opisa radnji koje prema članku 2.5 Pravilnika WADA-e udovoljavaju pojmu utjecanje, a u kontekstu standarda dokazivanja antidopinške povrede, koji je po mišljenju koautora nedovoljno određen, ostalo je na sudskoj praksi da u svakom konkretnom predmetu odredi kada je to poprilično izvjesno da su (primarno neodređene) radnje sportaša utjecale na nemogućnost provedbe ili nepravilnost provedenog postupka doping kontrole. Jer, prema Propisu, neki je događaj poprilično izvjestan, samo ako je više nego vjerojatan, ali $\mathrm{u}$ isto vrijeme i dalje nedokazan izvan razumne sumnje. Dakle, dispozitivnost arbitražnog vijeća da neke radnje, koje nisu opisane kao uzimanje zabranjenih supstanci, kvalificira kao radnje kojima zakon ex lege daje učinak (sankciju) poput

71 Kada je fizička manipuliacija uzorcima nesporna, po sili primjenjivog antidopinškog pravilnika utvrđuje se postojanje zabranjene metode, tj. povrede pravila o antidopingu zbog ,prekida lanca osoba koje su bile ovlaštene čuvati uzorke“.

72 Eng. comfortable satisfaction; vidi Boevski v. IWF, op. cit.

73 CAS 2013/A/3341, WADA v. Daniel Pineda Contreras i Čileanski olimpijski odbor, Pravorijek od 28. V. 2014.

74 Ibid., str. 21, točka 120. 
dokazanog uzimanja zabranjenih supstanci, nema jasno određene granice, već ovisi o uvjerenju Arbitražnog vijeća. Nastavno navedenom, kako iz predmeta Sun Yang, tako i iz ostale prikazane sudske prakse, evidentno je da su sva nastojanja okrivljenih osoba (sportaša) da dokažu kako nisu izvršili radnju koja nigdje nije jasno propisana kao utjecanje na postupak antidopinške kontrole, ali je ovlašteni tužitelj (uglavnom antidopinška agencija) smatra utjecanjem, u apsolutnom broju slučajeva - bez uspjeha.

S druge strane, a što se moglo iščitati kako iz slučaja Sun Yang, tako i iz slučaja Lise Nemec, ustaljena je praksa Arbitražnog suda za Sport, da ukoliko bi testirana osoba (sportaš) uspjela dokazati odstupanje (kontrolora) ovlaštenog tijela za provedbu doping kontrole od međunarodnih standarda za testiranja (ISTI), utoliko Tijelo koje provodi doping kontrolu ne poništava ex lege cijeli postupak dopinške kontrole, već se tada (tek) teret dokazivanja da takvo odstupanje nije uzrokovalo nepovoljni nalaz ${ }^{75}$ prebacuje na Tijelo koje provodi testiranje.

Iz navedenog zaključujemo da u postupku antidopinške kontrole prema pozitivnim propisima, ako Tijelo koje provodi dopinšku kontrolu prekrši jasno propisana pravila postupanja, ono i dalje može dokazivati da je testirana osoba koristila zabranjenu supstancu i tražiti izricanje propisane sankcije, dok ako Testirana osoba pri provedbi dopinške kontrole prekrši pravila postupanja koja su tek primjerice propisana, ona ne može dokazivati da nije koristila zabranjenu supstancu, već se ex lege prekršaj procesnih pravila smatra povredom antidopinških pravila. ${ }^{76}$

Samim time, vidljivo je da postoji znatna neravnoteža u procesnom položaju stranaka u antidopinškom postupku, te ako je već nemoguće zbog fluidnosti potencijalnih kršenja procesnih odredbi točno propisati koja se kršenja imaju smatrati utjecajem rezultat kojeg je sankcija identična testiranom pozitivnom uzorku, autori smatraju da bi se procesni položaj stranaka (ovlaštenog tužitelja i testirane osobe) uravnotežio odredbom prema kojoj bi utvrđenje povrede procesnih pravila od strane Tijela nadležnog za postupak testiranja (najčešće antidopinške agencije) rezultiralo poništajem cijelog postupka testiranja. Uz sve uvažavanje opasnosti od dopinga u sportu kao takvog, čini nam se da bi, čak i bez nužne formalne promjene pravnog okvira, bitno pomoglo davanje većeg značenja modernih dosega znanosti o tumačenju u pravu, što znači i davanje odgovarajućeg značenja ciljnom ili teleološkom tumačenju u pravu.

75 Rezultat analize uzorka.

76 Dok eventualno uspješno dokazivanje da nije kriv za povredu procesnih pravila antidopinške kontrole, sportašu može utjecati isključivo na visinu kazne, a ne i na poništavanje cijelog postupka antidopinške kontrole. 


\section{LITERATURA}

1. Bačić, Arsen; Bačić, Petar; Bagić, Snježana, et alt., ur. Kačer, Hrvoje, Sportsko pravo, Pravni fakultet Sveučilišta u Splitu, Split, 2018.

2. Kačer, Hrvoje; Kačer, Blanka, „(Poneke) pravne dvojbe u svezi dopinga“, Doping $u$ vrhunskom sportu, Hrvatski olimpijski odbor - Zdravstvena komisija, Zagreb, 2019.

3. Klarić, Petar; Vedriš Martin, Građansko pravo, Narodne novine, Zagreb, 2008.

4. Lewis, Adam; Taylor, Jonathan, Sport: Law and Practice, treće izdanje, Bloomsbury Professional, 2014.

5. Mandić, Oleg, Sistem i interpretacija prava, Narodne novine, Zagreb, 1971.

6. Muller, Anja, Doping im Sport als Strafbare Gesundheitsbeschadigung (\&\&223 Abs, 230 StGB)?, Nomos Verlagsgesellschaft, Baden-Baden, 1993.

7. Pajčić, Matko; Petković, Tonći, „Doping i kaznenopravna odgovornost“, Zbornik radova Pravnog fakulteta u Splitu, god. 45, 3/2008.

8. Pavčnik, Marijan, Teorija prava, Pravna obzorja, drugo dopunjeno izdanje, Cankarjeva založba, Ljubljana, 2001.

9. Pivalica, Dinko, „Postupak doping kontrole i terapijska izuzeća“, u: Doping $u$ vrhunskom sportu, Hrvatski olimpijski odbor - Zdravstvena komisija, Zagreb, 2019.

10. Pound, Dick, Inside the Olympics, Wiley, Toronto, 2004.

11. Pravni leksikon, Leksikografski zavod Miroslav Krleža, Zagreb, 2007.

12. Verroken, Michele, „A time for re-evaluation: the challenge to an athlete's reputation“, Drugs and Doping in Sport, Routledge-Cavendish, 2001.

13. Visković, Nikola, Teorija države i prava, Birotehnika, Zagreb, 2001.

\section{PROPISI}

1. Zakon o potvrđivanju Međunarodne konvencije protiv dopinga u športu, „Narodne novine" MU 7/2007.

\section{SUDSKA PRAKSA (CAS)}

1. CAS 2019/A/6148, WADA v. Sun Yang i FINA, Pravorijek od 28. II. 2020.

2. CAS 2016/A/4458, Lisa Christina Nemec v. Hrvatska agencija za toksikologiju i antidoping (HZTA), Pravorijek od 27. IV. 2017.

3. CAS 2016/A/4631.

4. CAS 2013/A/3342.

5. CAS 2013/A/3341, WADA v. Daniel Pineda Contreras i Čileanski olimpijski odbor, Pravorijek od 28. V. 2014.

6. CAS 2013/A/3077.

7. CAS 2012/A/2791, WADA v. Malaysia Athletic Federation, Jumaludin et al., Pravorijek od 24. V. 2013. 
8. CAS 2005/A/925, Laura Dutra de Abreu Mancini de Azevedo v. FINA, Pravorijek od 24. I. 2006., para. 75

9. CAS 2004/A/607, Boevski v. International Weightlifting Federation (IWF), Pravorijek od 6. XII. 2004.

10. CAS 98/211, Michelle Smith De Bruin v. FINA, Pravorijek od 7. VI. 1999.

\section{INTERNETSKI IZVORI}

1. Pravilnik WADA-e, Montreal - Quebec, (2015), Predgovor, dostupno na www.wadaama.org, uvid izvršen 20. IV. 2020., 20,00.

2. www.telegram.hr, Povijest dopinga..., uvid izvršen 1. V. 2020., 18,00.

\section{STANDARD OF PROOF AND LEGAL ISSUES OF DOPING IN THE CASE LAW OF THE CAS, WITH SPECIAL EMPHASIS TO THE CURRENT DECISION IN THE CASE SUN YANG}

The paper analyzes the situation in both legal regulations and in the case law of the CAS, with special emphasis to the specific case. Among other things, the conclusion in the paper is that there is a significant imbalance in the procedural position of the parties in the anti-doping procedure and changes de lege ferenda are needed, but until these changes occur, it is necessary to apply the rules of the target interpretation for purpose of protecting legal certainty and the rule of the law.

Key words: doping, legal issues, case law of the CAS, standard of proof, target interpretation 